\title{
Perceived Social Support of HIV/AIDS Orphans
}

\author{
Shikha Verma ${ }^{1}$, Dr. Swaran Lata ${ }^{2}$
}

\section{ABSTRACT}

The present study examined the group and gender deference in Perceived social support (PSS) on a sample of HIV/AIDS orphans and non- HIV/AIDS orphans. The sample of the study consisted of 236 orphans (116 HIV/AIDS orphans and 120 non- HIV/AIDS orphans) the mean age of HIV/AIDS orphans, 11.66 years and mean age of non-HIV/AIDS orphans, 11.78 years living in the north Indian orphanages. The tools employed for present study is PSS scale for children consisting of 30 items and comprising of three subscales assessing the source of the emotional support (i.e., family, friends, or teacher). Result related to MANOVA indicates that significant group difference $(\mathrm{F}=2.66, \mathrm{p}<0.05)$ and significant gender difference $(\mathrm{F}=2.66, \mathrm{p}<0.05)$ was found in HIV/AIDS orphans and non-HIV/AIDS orphans on perceived social support. The present research explored low PSS of HIV/AIDS orphans living in Indian orphanages. PSS plays a protective role in dealing with psychosocial outcomes of HIV/AIDS orphans. Strong perception of support from cares, siblings, school teachers, school principal, friends, and others may reduce the deleterious effects of exposure to illness and psychological problems.

Keywords: HIV/AIDS Orphans, Non- HIV/AIDS orphans and Perceived social support

HIV/AIDS is one of the most destructive diseases humankind has ever faced. Human Immunodeficiency Virus (HIV), is the virus that causes AIDS. HIV destroys certain blood cells that are crucial to the normal functioning of the immune system, which defends the body against illness. Acquired Immuno Deficiency Syndrome (AIDS) occurs when the immune system is weakened by HIV virus to the point where a person is susceptible to numerous opportunistic infections or diseases.

Today, India is the home to the largest number of AIDS orphans in the world (UNAIDS, 2013). It is expected to become the next epicenter of AIDS orphan crises. In India, over 31 million children are orphaned due to various causes including HIV (UNICEF, 2010). In India about 170,000 adult deaths per year (of the total 2.3 million adults living with HIV) can be traced to HIV (NACO, 2010-11). This makes the problem of AIDS orphans significant in our country.

\footnotetext{
${ }^{1}$ Research scholar, Psychology Department, Faculty of Social Sciences, Banaras Hindu University, Varanasi, U.P., India

${ }^{2}$ Assistant Professor, Psychology Department, Faculty of Social Sciences, Banaras Hindu University, Varanasi, U.P., India

*Responding Author

(C) 2016 I S Verma, S Lata; licensee IJIP. This is an Open Access Research distributed under the terms of the Creative Commons Attribution License (http://creativecommons.org/licenses/by/2.0), which permits unrestricted use, distribution, and reproduction in any Medium, provided the original work is properly cited.
} 


\section{Perceived Social Support of HIV/AIDS Orphans}

HIV/AIDS Orphan is a relatively new concept. A child under 18 years who has lost either or both parents because of AIDS is HIV/AIDS orphans and is further categorized as a maternal, paternal and double orphan (UNAIDS, UNICEF \& USAIDS (2004). Chitiyo, Changara, and Chitiyo (2008) defined an AIDS orphan as a child who has lost one or both parents to HIV/AIDS.

Social support has been defined as an exchange of resources between two individuals perceived by the provider or recipient to be intended to enhance the wellbeing of the recipient (Shumaker and Brownell, 1984). Perceived social support (PSS) is a term encompassing a variety of characteristics of an individual's social world and relationship between the individual and the social environment (Haber, Cohen, Lucas, and Baltes, 2007). It is defined as the perception or experience that social support is available if someone liked to reach the support of another person (Sarason et al., 1983) and as cognitive variable influencing interactions with other people (Lakey and Cassady, 1990). It can be defined as a perceived financial, physical, and emotional help from family, friends, and the community at large (Dirkzwager, Bramsen, and van der Ploeg, 2003). Although definitions vary, PSS can be defined as those social interactions that provides individuals with actual assistance or embeds them into a web of social relations perceived to be caring and readily available in times of need (Hobfoll, 1989). PSS has been shown to be consistently linked to better health and psychological well-being outcome (Williams, 1995; Sacco, and Yanover, 2006; Haber, Cohen, Lucas, and Baltes, 2007), psychological adjustment, improved efficacy, self-esteem and social competence.

Social support systems have been shown to be effective in addressing mental health and behavioral problems among HIV/AIDS orphans, particularly depression, conduct problems and problematic behaviors (Lee, Deteis, Rotheram-Borus, and Duan, 2007). While there is currently a growing body of global literature on the well-being of HIV/AIDS orphans (Cluver and Gardner, 2007; Lee, Detels, Rotheram-Borus, and Duan, 2007; Li et al., 2009; Zhao et al., 2007), limited research and data are available regarding the PSS of HIV/AIDS orphans (Verma \& Lata, 2015). Hong et al., (2010), examined the relationship between PSS and psychosocial distress of HIV/AIDS orphans. A strong association was found between PSS and psychosocial distress, which was consistent with global literature on the 'buffer' function of PSS. All aspects of social support, including support from family, friends, teachers and significant others are imperative for children affected by HIV/AIDS. Data on protective role of PSS on trauma in HIV/AIDS orphans is limited. Cluver, Fincham, and Seedat, 2009, examined the relationship between PSS and Post traumatic Stress Disorder (PTSD). Findings from this study revealed that substantial amount of social support from cares, school staff, and friends may reduce the adverse effects of exposure to trauma, and should be included as the main theme of intervention designed to improve psychological outcomes of HIV/AIDS orphans. Furthermore, the study suggested that PSS may act as a protective factor against the onset of clinical-threshold PTSD (Verma \& Lata, 2015).

HIV/AIDS orphans have poor mental health, and their psychosocial wellbeing vary by their orphan hood status (Fang et al., 2009; Zhao et al., 2007). They have lower PSS as compared to other children (Ferreira, Keikelame, and Mosaval, 2001; Manuel, 2002) due to the loss of their mother, father or both. They lose close human relationships as a result of changing caregivers, repeated moves and 
bereavement (Cluver and Gardner, 2007). Under these circumstances, social support is worth utilizing as a low-cost critical resource for the care of HIV/AIDS orphans (Thurman et al., 2006) as it can reduce the incidence of mental illness (Callaghan and Morrissey, 1993).

\section{RATIONALE OF THE PRESENT STUDY}

HIV/AIDS is an emerging area of research. Research on Indian HIV/AIDS orphans is limited. Present research is being conducted for understanding the state of HIV/AIDS orphans in India. In literature survey numerous studies were found related to HIV/AIDS children but research on HIV/AIDS orphans is scarce in India. Due to lack of support and care, HIV/AIDS orphans are at higher risk of bad health and nutritional problems. They are forced to leave school, engage in labour or prostitution, suffer from depression and anger, and engage in risky behaviours etc. Lack of social support owing to illness or death of family members lead to distorted cognitions of themselves and others which of itself lead to reduced perceptions of social support. There is paucity of studies on PSS among HIV/AIDS orphans.

On the basis of review of literature the following objectives were formulated for the study:

1. To assess the group differences in PSS in HIV/AIDS orphans and non-HIV/AIDS orphans.

2. To assess the gender differences in PSS in HIV/AIDS orphans and non-HIV/AIDS orphans.

On the basis of review of literature the following hypotheses were formulated for the study:

$\mathrm{H}_{1}$. PSS would be lower in HIV/AIDS orphans than non HIV/AIDS orphans.

$\mathrm{H}_{2}$. There would be significant gender differences in PSS in HIV/AIDS orphans than nonHIV/AIDS orphans.

\section{Research Design of the study}

The study is a ex-post facto research design. This is because the children were already orphaned. In the study 2x2 factorial design is applied. Two groups of orphans (HIV/AIDS orphans and non-HIV/AIDS orphans) and gender (boys and girls) as two factors were used.

\section{Sample}

With help of the snowball sampling 236 orphans (131 boys and 105 girls) were selected for the study. 116 were HIV/AIDS orphans (71 boys and 45 girls) and 120 were non-HIV/AIDS orphans (60 boys and 60 girls). Mean age of HIV/AIDS orphans was 11.98 years (boys mean age was 10.17 years and girls mean age was 12.15 years), mean age of non-HIV/AIDS orphans was 12.65 years (boys mean age was 13.15 years and girls mean age was 12.31 years). Data were collected from different orphanages of north India with the approval from the authorities.

\section{Measures}

\section{Demographic sheet:}

Perceived Social Support Scale for Children: It is self-developed scale in hindi. It consists of 30 items and comprises of three subscales assessing the sources of the PSS (i.e., family, friends, and 
teacher) using a 5-point response option (ranging from 1 = 'strongly disagree' to 5 = 'strongly agree') The alpha-coefficient is .94.

\section{Pilot Study}

The self-constructed PSS scale in Hindi of 54 items was used for pilot study. Pilot study was conducted on the research sample of 32 HIV/AIDS orphans, age ranging from 10 to 17 years. The purpose of the pilot study was to examine the appropriateness, understanding and finalizing the constructed scale. After conducting the pilot study the reliability of all items was calculated with the help of SPSS. Range of item total correlation was found to be .797 to .120. 10 items were selected from each domain namely- friend, teacher and family thus finally total 30 items were retained in the final questionnaire.

\section{Data Collection}

Being assured of the appropriateness of the scale, data collection for the main study was started. Before starting the data collection, consent was taken from the caregivers of the orphans. All information related to study was given to participant verbally and in written form. Further process was done only after their consent had been received for participation in the study. A rapport was established with the participants before the test administration, so that they may feel free to give their response. They were encouraged to answer all items. No individual names or other identifiers were used in the data sheets. All subjects completed the demographic information and PSS scale for children.

\section{Statistical Analysis}

The collected data were coded and entered into the Statistical Program for the Social Sciences (SPSS version 17.0) for analysis. Descriptive statistics was applied for each of the variables. Coded scores were analysed in term of ANOVA and MANOVA for computing the differences in group of orphans and gender. Tukey's test was used for multiple comparisons of means.

\section{RESULTS}

\section{Group Differences in PSS}

Results related to group differences between HIV/AIDS orphans and non-HIV/AIDS orphans on PSS has been presented in the Table 1 and Figure 1.

\section{Table 1 Group Differences inPSS}

\begin{tabular}{|c|c|c|c|c|c|}
\hline \multirow{3}{*}{ Dimensions of PSS } & \multicolumn{4}{|c|}{ Group of Orphans } & \multirow{3}{*}{$\mathbf{F}$} \\
\hline & \multicolumn{2}{|c|}{$\begin{array}{l}\text { HIV/AIDS Orphans } \\
(n=116)\end{array}$} & \multicolumn{2}{|c|}{$\begin{array}{l}\text { Non-HIV/AIDS } \\
\text { Orphans } \\
(n=120)\end{array}$} & \\
\hline & Mean & $S D$ & Mean & $S D$ & \\
\hline Friend PSS & 33.28 & 7.20 & 35.34 & 12.54 & 2.095 \\
\hline Teacher PSS & 31.88 & 8.62 & 35.89 & 12.71 & $7.557 * *$ \\
\hline Family PSS & 34.92 & 8.21 & 37.90 & 12.64 & $4.356 *$ \\
\hline
\end{tabular}

${ }^{*} \mathrm{p}<0.05, * * \mathrm{p}<0.01$ 
Figure 1 Bar Diagram of Group Differences in Perceived Social Support

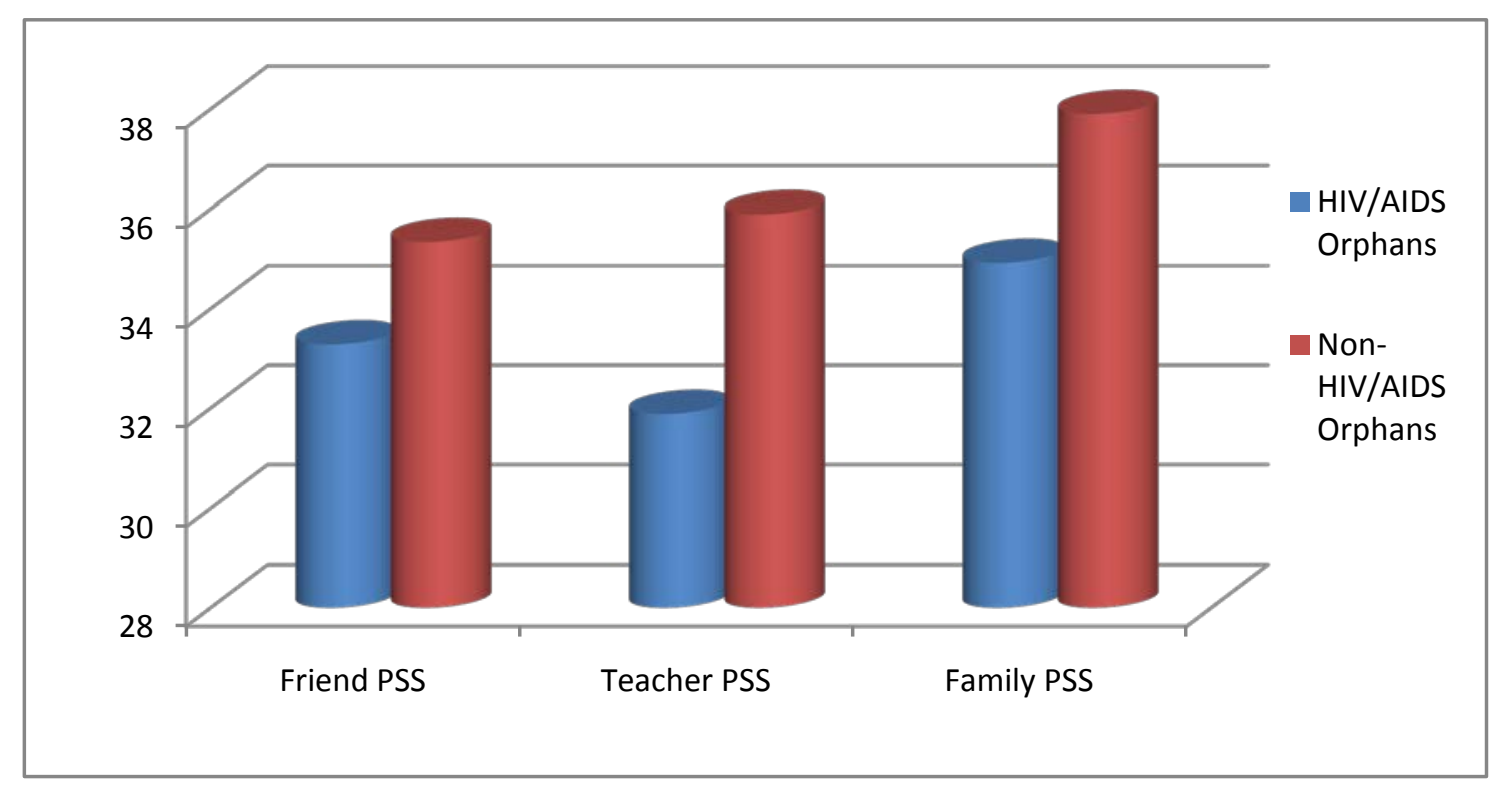

Table1 and Figure1 shows that mean and SD values of HIV/AIDS orphans and non-HIV/AIDS orphans on friend PSS was 33.28 (7.20) and 35.34 (12.54), on teacher PSS was 31.88 (8.62) and 35.89 (12.71) and on family PSS was 34.92 (8.21) and 37.90 (12.64) respectively.

In MANOVA the four most commonly used multivariate tests (Pillai's Criterion, Wilks's Lambda, Hotelling's Trace and Roy's Largest Root) indicates that significant difference was found between HIV/AIDS orphans and non-HIV/AIDS orphans on PSS ( $F=2.66, \mathrm{p}<0.05)$. Univariate statistical test (ANOVA) for each dimension of PSS shows significant difference between HIV/AIDS orphans and non-HIV/AIDS orphans on teacher and family PSS $(\mathrm{F}=7.56, \mathrm{p}<0.01$ and $\mathrm{F}=4.36, \mathrm{p}<0.05)$. Insignificant difference $(\mathrm{F}=2.10, \mathrm{p}>0.05)$ was found between the two group of orphans - HIV/AIDS orphans and non-HIV/AIDS orphans on friend perceived social support. This is confirmed by the means of group differences reported in Table 1 and Figure.1.

\section{Gender Differences in PSS}

Result related to gender difference in HIV/AIDS orphan and non-HIV/AIDS orphan on PSS has been presented in Table 2 and Figure 2. 
Table 2 Gender Differences in PSS

\begin{tabular}{|c|c|c|c|c|c|}
\hline \multirow{4}{*}{ Dimensions of PSS } & \multicolumn{4}{|c|}{ Group of Orphans } & \multirow{4}{*}{$\mathbf{F}$} \\
\hline & \multicolumn{2}{|c|}{ HIV/AIDS orphans } & \multicolumn{2}{|c|}{ Non-HIV/AIDS orphans } & \\
\hline & $\begin{array}{l}\text { Boys } \\
(n=71)\end{array}$ & $\begin{array}{l}\text { Girls } \\
(n=45)\end{array}$ & $\begin{array}{l}\text { Boys } \\
(n=60)\end{array}$ & $\begin{array}{l}\text { Girls } \\
(n=60)\end{array}$ & \\
\hline & Mean (SD) & Mean (SD) & Mean (SD) & Mean (SD) & \\
\hline Friend PSS & $\begin{array}{l}33.85^{\mathrm{a}} \\
(6.66)\end{array}$ & $\begin{array}{l}32.71^{a} \\
(8.02)\end{array}$ & $\begin{array}{l}36.30^{\mathrm{a}} \\
(9.78)\end{array}$ & $\begin{array}{l}34.38^{a} \\
(14.83)\end{array}$ & 1.16 \\
\hline Teacher PSS & $\begin{array}{l}32.37^{\mathrm{a}} \\
(7.92)\end{array}$ & $\begin{array}{l}31.40^{\mathrm{a}} \\
(9.68)\end{array}$ & $\begin{array}{l}38.28^{b} \\
(10.06)\end{array}$ & $\begin{array}{l}33.50^{a} \\
(14.59)\end{array}$ & $4.51^{*}$ \\
\hline Family PSS & $\begin{array}{l}35.24^{\mathrm{a}} \\
(8.29)\end{array}$ & $\begin{array}{l}34.60^{\mathrm{a}} \\
(8.17)\end{array}$ & $\begin{array}{l}40.38^{b} \\
(9.18)\end{array}$ & $\begin{array}{l}35.42^{a} \\
(15.02)\end{array}$ & $3.76^{*}$ \\
\hline
\end{tabular}

${ }^{*} \mathrm{p}<0.05,{ }^{* *} \mathrm{p}<0.01$

Figure 2 Graphical Presentations of Gender Differences

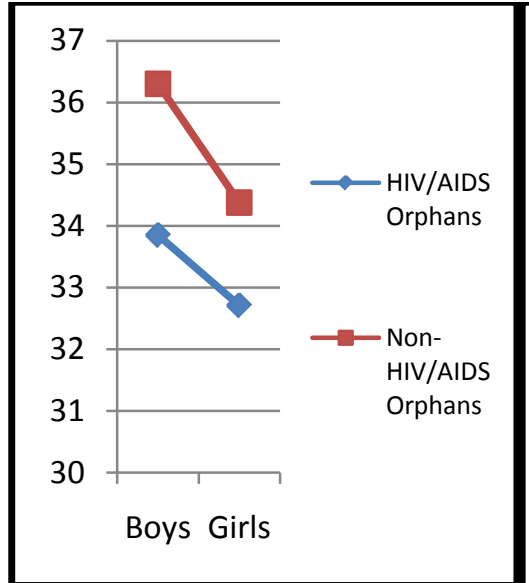

Friend PSS

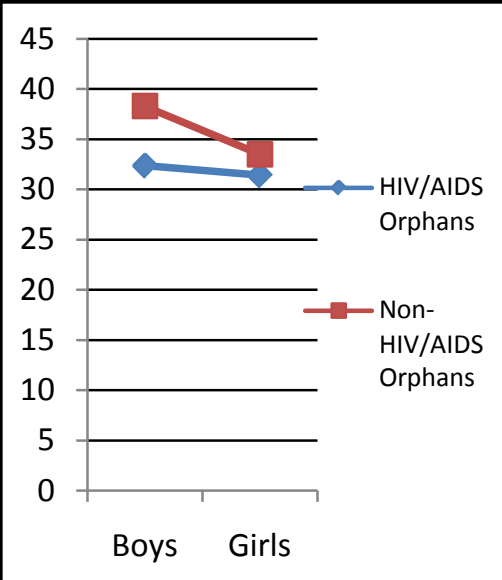

Teacher PSS

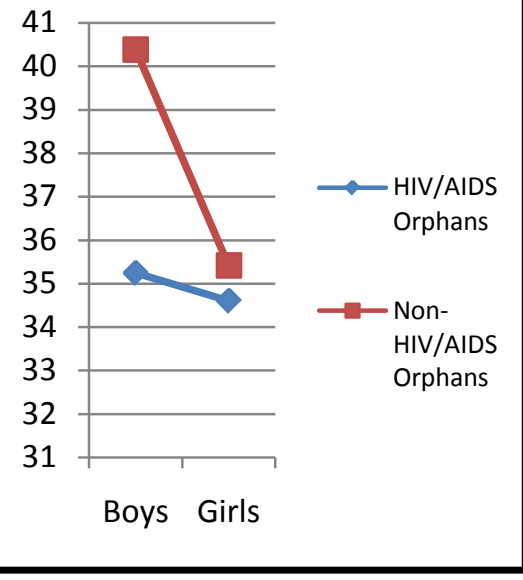

Family PSS

Table 2 and Figure 2 shows that the mean and SD value of HIV/AIDS orphan boys and girls on friend PSS were 33.85 (6.66) and 32.71 (8.02) and non-HIV/AIDS orphan boys and girls were 36.30(9.78) and 34.38 (14.83). The mean and SD value of HIV/AIDS orphan boys and girls on teacher PSS were 32.37 (7.92) and 31.40 (9.68) and non-HIV/AIDS orphan boys and girls were 38.28 (10.06) and 33.50 (14.59). The mean and SD value of HIV/AIDS orphan boys and girls on family PSS were 35.24 (8.29) and 34.60 (8.17) and non-HIV/AIDS orphan boys and girls were 40.38 (9.18) and 35.42 (15.02).

In MANOVA the four most commonly used multivariate tests (Pillai’s Criterion, Wilks's Lambda, Hotelling's Trace and Roy's Largest Root) were employed. Each of the four measures indicates that significant gender difference was found between HIV/AIDS orphans and non-HIV/AIDS orphans on PSS $(\mathrm{F}=2.76, \mathrm{p}<0.05)$. Univariate statistical test (ANOVA) for each dimension of PSS shows significant gender difference between HIV/AIDS orphans and non-HIV/AIDS orphans on teacher and 
family PSS ( $\mathrm{F}=4.51, \mathrm{p}<0.05$ and $\mathrm{F}=3.76, \mathrm{p}<0.05)$. Insignificant gender difference was found between HIV/AIDS orphans and non-HIV/AIDS orphans on friend PSS ( $F=1.16, p>0.05)$. This is confirmed by the means of group differences by gender reported in Table 2 and Figure 2.

Figure 3 Bar Diagram of Tukey's-HSD Test for Gender Difference on PSS between HIV/AIDS Orphans and Non-HIV/AIDS Orphans

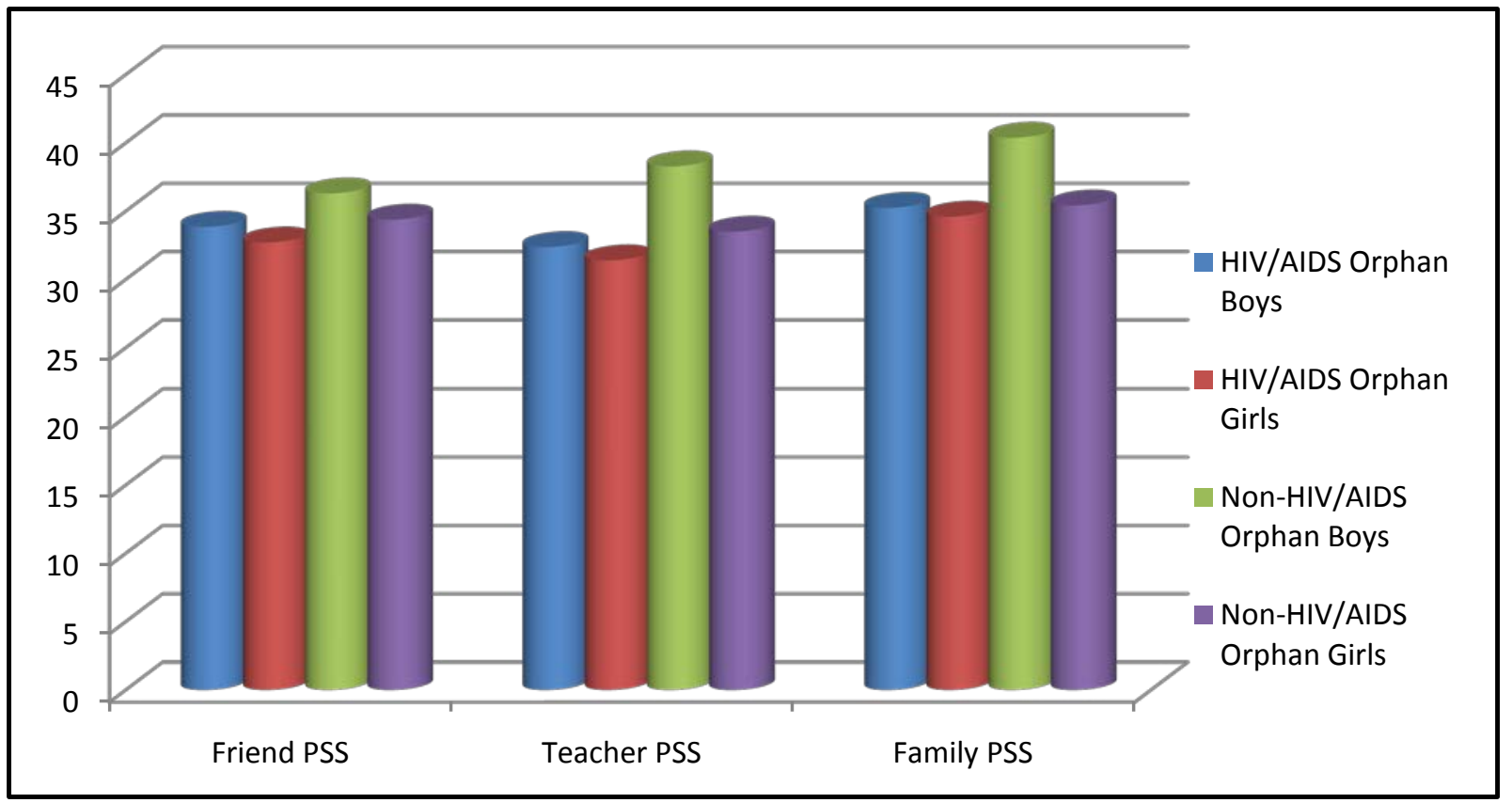

Results related to post hoc comparison of means with the help of Tukey's- HSD test are presented in Table 2. Figure 3 shows that insignificant mean difference was found in friend PSS between all the possible groups. Significant mean difference was found in teacher PSS between HIV/AIDS orphan boys and non-HIV/AIDS orphan boys (-5.91, $\mathrm{p}<0.05)$, HIV/AIDS orphan girls and non-HIV/AIDS orphan boys (-6.88, $\mathrm{p}<0.01)$, and non-HIV/AIDS orphan boys and non-HIV/AIDS orphan girls (-4.78, $\mathrm{p}>0.05)$. Significant mean difference was found in family PSS between HIV/AIDS orphan boys and non-HIV/AIDS orphan boys (-5.14, $\mathrm{p}<0.05)$, HIV/AIDS orphan girls and non-HIV/AIDS orphan boys $(-5.78, \mathrm{p}<0.05)$, and non-HIV/AIDS orphan boys and non-HIV/AIDS orphan girls $(-4.97, \mathrm{p}>0.05)$.

\section{DISCUSSION}

PSS is the perceived financial, physical and emotional help from family, friends, teachers and the community at large. It is a recipient's subjective judgment that providers will offer (or have offered) effective help during times of need. PSS scale comprises of three subscales assessing the source of the financial, physical and emotional support from friends, teachers and family. 


\section{Group difference in PSS}

Result related to MANOVA indicates that significant group difference was found in HIV/AIDS orphans and non-HIV/AIDS orphans on perceived social support. Thus, the Hypothesis 1 is accepted on the basis of this observation. PSS of HIV/AIDS orphans was lower than non-HIV/AIDS orphans. This finding has been supported by Nyamukapa, et al., (2010) and $\mathrm{Xu}$, et al., (2009). Lower PSS of HIV/AIDS orphans may be due to the prevalence of HIV related stigma, bullying, discrimination, HIV infection, inadequate care, physical abuse, school dropout and failure, food insecurity, changes in the interpersonal relationship, less care and support from the friends, teachers, rehabilitation centers and caregivers. The HIV/AIDS orphans are unable to talk about their personal problems with their friends and regularly attend school due to poor health. They had limited interactions with their teachers and friends. They perceived that their family, the orphanage staff supported them in their medical health care but they did not motivate and helped them for academics and other life engagements.

\section{Friend PSS}

Result related to ANOVA indicates insignificant group difference in HIV/AIDS orphans and nonHIV/AIDS orphans on friend perceived social support. HIV/AIDS orphans perceived lower friend PSS than non-HIV/AIDS orphans. HIV/AIDS orphans realized that their friends were playing, talking and studying with them but they could not talk about their personal problems with them due to shame and guilt. They also do not feel comfortable sharing their problems with their friend. They do not find them capable enough to solve their problems. Thus they perceived low social support from friends. Study reveals that most of the HIV/AIDS orphans strongly disagreed with the items of PSS scale for children like- I can talk about my personal problems with my friend (item no. 1) and My friends are always with me at the time of need (item no. 5).

\section{Teacher PSS}

Result related to ANOVA indicates significant group difference in HIV/AIDS orphans and nonHIV/AIDS orphans on teacher perceived social support. HIV/AIDS orphans perceived lower teacher PSS than non-HIV/AIDS orphans. HIV/AIDS orphans do not go to school regularly due to poor health. They perceived low affection, attachment and interaction from their teachers. Most of the HIV/AIDS orphans strongly disagreed with the items like- My teacher is always with me at the time of need (item no. 13) and My teacher cares of my feelings (item no. 15).

\section{Family PSS}

Result related to ANOVA indicates significant group difference in HIV/AIDS orphans and nonHIV/AIDS orphans on family perceived social support. HIV/AIDS orphans perceived lower family PSS than non-HIV/AIDS orphans. HIV/AIDS orphans perceived that their family took great care of their health but they did not encourage them for better studies and other aspects of life. Most of the HIV/AIDS orphans strongly disagreed with the items like- My family helps me in studies (item no. 23) and My family motivates me to achieve good grades in class (item no. 26). 


\section{Perceived Social Support of HIV/AIDS Orphans}

\section{Gender difference in PSS}

Result related to MANOVA indicates that significant gender difference was found in HIV/AIDS orphans and non-HIV/AIDS orphans on perceived social support. Thus, the Hypothesis 2 is accepted on the basis of this observation.

\section{Friend PSS}

Result related to ANOVA indicates insignificant gender difference in HIV/AIDS orphans and nonHIV/AIDS orphans on friend perceived social support. Further Tukey's-(HSD) Test result also indicates insignificant gender difference between HIV/AIDS orphan boys and HIV/AIDS orphan girls on friend perceived social support. HIV/AIDS orphan boys and girls perceived lower friend perceived social support. HIV/AIDS orphan boys and girls due to HIV infection and opportunistic infections witnessed insufficient supports and care from their friends. Most of the HIV/AIDS orphans strongly disagreed with the items like- I can talk about my personal problems with my friend (item no. 1) and My friend wants to be with me (item no. 8).

Insignificant gender difference was also found between non-HIV/AIDS orphan boys and nonHIV/AIDS orphan girls on friend perceived social support. Non-HIV/AIDS orphan boys and girls both are free from infection or any other medical problem. They experience PSS from their friends during times of need. Mean value depicts that friend PSS of non-HIV/AIDS orphan boys were slightly more than non-HIV/AIDS orphan girls. The reasons attributed to it can be that they could easily share their problems with their friends. They feel that their friends love them and are readily available to comfort them at the time of need. Most of the non-HIV/AIDS orphan boys strongly agreed with the items likeMy friend loves me (item no. 7) and When I'm upset, my friend comforts me (item no. 2).

\section{Teacher PSS}

Result related to ANOVA indicates significant gender difference in HIV/AIDS orphans and nonHIV/AIDS orphans on teacher perceived social support. Further, Tukey's-(HSD) Test result also indicates insignificant gender difference between HIV/AIDS orphan boys and HIV/AIDS orphan girl son teacher perceived social support. HIV/AIDS orphans due to several health problems visualize insufficient supports and care from their teachers. They observe that their teachers are not compassionate and stigmatized due to HIV infection. Most of the HIV/AIDS orphan boys and girls strongly disagreed with the items like- My teacher worries about my future (item no. 17) and My teacher is always with me at the time of need (item no. 26).

Significant gender difference was found between non-HIV/AIDS orphan boys and non-HIV/AIDS orphan girls on teacher perceived social support. Thus, ANOVA result was significant due to significant gender difference between non-HIV/AIDS orphan boys and non-HIV/AIDS orphan girls on teacher perceived social support. Non-HIV/AIDS orphan boys and girls are healthy and experience PSS from their teachers during times of need. Their teachers are passionate and help them because of their circumstances and destiny. Mean value depicts that teacher PSS of non-HIV/AIDS orphan boys were higher than non-HIV/AIDS orphan girls. Most of the non-HIV/AIDS orphan boys agreed with the 
items like-My teacher gives good suggestions and advice about my problems (item no. 20) and My teacher helps me in studies (item no. 12).

\section{Family PSS}

Result related to ANOVA indicates significant gender difference in HIV/AIDS orphans and nonHIV/AIDS orphans on family perceived social support. Further, Tukey's-(HSD) Test also indicates insignificant gender difference between HIV/AIDS orphan boys and HIV/AIDS orphan girls on family perceived social support. HIV/AIDS orphans experience insufficient support, help and care from their family i.e. the orphanage. They also miss the family environment. Most of the HIV/AIDS orphan boys and girls strongly disagreed with the items like- My family makes me laugh when I am crying (item no. 25) and My family always motivates me towards better living (item no. 28).

Significant gender difference was found between non-HIV/AIDS orphan boys and non-HIV/AIDS orphan girls on family perceived social support. Thus, ANOVA result was significant due to significant gender difference between non-HIV/AIDS orphan boys and non-HIV/AIDS orphan girls on family perceived social support. Non-HIV/AIDS orphan boys and girls experience equal PSS from their family during times of need. Mean value depicts that family PSS of non-HIV/AIDS orphan boys was higher than non-HIV/AIDS orphan girls. The reasons attributed to it can be that being orphans, they live normal healthy life. Their family motivates them toward better living and help in their studies for achieving better career as compared to non-HIV/AIDS orphan girls. Most of the non-HIV/AIDS orphan boys strongly agreed with the items like- My family always motivates me towards better living (item no. 28) and My family helps me in studies (item no. 23).

\section{CONCLUSION}

Result related to MANOVA indicates that significant group difference was found in HIV/AIDS orphans and non-HIV/AIDS orphans on perceived social support. PSS was lower in HIV/AIDS orphans as compared to non-HIV/AIDS orphans. Result related to MANOVA indicates that significant gender difference was found in HIV/AIDS orphans and non-HIV/AIDS orphans on perceived social support. Substantial amount of social support from family, care takers, friends, school staff and mental health services should be provided to alleviate stressful life events and improve psychosocial wellbeing. Peergroup intervention would be effective in enhancing PSS of HIV/AIDS orphans. Appropriate interventions should be undertaken to promote school performance of children orphaned by AIDS and to mitigate the interactive stressors of AIDS-orphan hood and trauma exposure on childhood PTSD. Community interventions should be promoted to improve the situations of these children e. g. educational assistance, home-based care, legal protection, and psychosocial support. Counseling services should be recommended as a specific psychological intervention.

\section{LIMITATIONS AND SUGGESTIONS FOR FUTURE RESEARCH}

The limitations observed during the process of completion of present study are being presented and may be applied for improving future research on HIV/AIDS orphans. The present study was conducted on the small sample. Future research may consider a wider range sample and longer study period. The 
present study examined differences between double HIV/AIDS orphans and non-HIV/AIDS orphans but comparison between double orphans, paternal orphans and maternal orphans were not included in the present study. Future research may focus on including comparison between all types of HIV/AIDS orphans. The present study focuses on gender difference but in HIV/AIDS orphans group, numbers of girls are less than HIV/AIDS orphans boys. This is because there are few HIV/AIDS orphan girls enrolled in North Indian orphanages. Future research may include equal number of HIV/AIDS orphans boys and girls for better interpretation of the results. The present study explored the current status of PSS but did not plan any intervention programs for their betterment. Future research may include interventions for their overall development and betterment.

\section{IMPLICATIONS FOR FUTURE RESEARCH}

The present research explored low PSS of HIV/AIDS orphans living in Indian orphanages. PSS plays a protective role in dealing with psychosocial outcomes of HIV/AIDS orphans. Strong perception of support from cares, siblings, school teachers, school principal, friends, and others may reduce the deleterious effects of exposure to illness and psychological problems. The study emphasizes the provision of peer group intervention programs in the orphanage settings for developing the feeling of togetherness and brotherhood and thus enhancing PSS of HIV/AIDS orphans.

\section{REFERENCES}

Callaghan, P., \& Morrissey, J. (1993). Social support and health: A review. Journal of Advanced Nursing, 18, 203-210.

Chitiyoa, M., Changarab, D. M., \& Chitiyo, G. (2008). Providing psychosocial support to special needs children: A case of orphans and vulnerable children in Zimbabwe. International Journal of Educational Development, 28, 384-392.

Cluver, L., \& Gardner, F. (2007). Mental health of children orphaned by AIDS: A review of international and Southern African research. Journal of Child and Adolescent Mental Health, 19(1), 1-17.

Cluver, L., Fincham, D. S., \& Seedat, S. (2009). Posttraumatic Stress in AIDS-Orphaned Children Exposed to High Levels of Trauma: The Protective Role of Perceived Social Support. Journal of Traumatic Stress, 22, (2), 106-112.

Dirkzwager, A., Bramsen, I., \& van der Ploeg, H. (2003). Social support, coping, life events, and posttraumatic stress symptoms among former peacekeepers: A prospective study. Personality and Individual Differences, 34, 1545-1559.

Fang, X., Li, X., Stanton, B., Hong, Y., Zhang, L., Zhao, G., et al. (2009). Parental HIV/AIDS and psychosocial adjustment among rural Chinese children. Journal of Pediatric Psychology, 34(10), 1053-1062.Ferreira, Keikelame, and Mosaval, 2001;

Haber, M. G., Cohen, J. L., Lucas, T., \& Baltes, B. B. (2007). The relationship between self-reported received and perceived social support: A meta-analytic review. American Journal of Community Psychology, 39, 133-144.

Hobfoll, S. E. (1989). Stress, Culture and Community. The Psychology and Philosophy of Stress. Plenum Press. 
Hong, Y., Li, X., Fang, X., Zhao, G., Lin, X., Zhang, J., Zhao, J., \& Zhang, L. (2010). Perceived Social Support and Psychosocial Distress among Children Affected by AIDS in China. Journal of Community Mental Health, 46, 33-43.

Lakey, B., \& Cassady, P. B. (1990). Cognitive processes in perceived social support. Journal of Personality and Social Psychology, 59, 337-343. doi:10.1037/0022-3514.59.2.337

Lee, S. J., Detels, R., Rotheram-Borus, M. R., \& Duan, N. (2007). The Effect of Social Support on Mental and Behavioral Outcomes Among Adolescents With Parents With HIV/AIDS. American Journal of Public Health, 97, 10.

Li, X., Fang, X., Stanton, B., Zhao, G., Lin, X., Zhao, J., Zhang, L., Hong, Y., \& Chen, X. (2009). Psychometric Evaluation of the Trauma Symptoms Checklist for Children (TSCC) among Children Affected by HIV/AIDS in China. AIDS Care, 21(3), 261-270. .10.1080/09540120802195119 [PubMed: 19280403]

Manuel, P. (2002). Assessment of Orphans and their Caregivers’ Psychological Well-being in a Rural Community in Central Mozambique. MSc Thesis, Institute of Child Health, London.

NACO (2010-11). NACO Annual Report 2010-11. National AIDS Control Organization, New Delhi. Available http://www.nacoonline.org/upload/REPORTS/NACO\%20Annual\%20Report\%20201011.pdf

Nyamukapa, C.A., Gregsona, S., Wambeb, M., Mushoreb, P., Lopmana, B., Mupambireyib, Z., Nhongob, K., \& Jukes, M.C.H. (2010). Causes and consequences of psychological distress among orphans in eastern Zimbabwe. AIDS Care, 22, (8), 988-996.

Sacco, W. P., \& Yanover, T. (2006). Diabetes and depression: the role of social support and medical symptoms. Journal of Behavioral Medicine, 29, 550-552.

Sarason, I. G., Levine, H.M., \& Basham, R.B. (1983). Assessing social support: The Social Support Questionnaire. Journal of Perspective of Social Psychology, 44, 127-139.

Shumaker, S. A., \& Brownell, A. (1984). Toward a theory of social support: Closing conceptual gaps. The Journal of Social Issues, 40, 11-36.

Thurman, T.R., Snider, L., Boris, N., Kalisa, E., Nkunda Mugarira, E., Ntaganira, J., \& Brown, L. (2006). Psychosocial support and marginalization of youth-headed households in Rwanda. AIDS Care. 18(3), 220-229.

UNAIDS (2013). India HIV and AIDS estimates- See more at http://www.avert.org/hiv-aidsindia.htm\#sthash.adlUc9P6.dput

UNAIDS, UNICEF, USAID (2004). Children on the brink: A joint report of new orphan estimates and a framework for action.

UNICEF (2010). Children and AIDS: Fifth Stocktaking Report, 2010. UNICEF, New York. Available at: http://www.unicef.org/publications/files/Children_and_AIDSFifth_Stocktaking_Report_2010 EN.pdf

Verma, S. \& Lata, S. (2015).Perceived social support of HIV/AIDS orphans: A Review. Vulnerable Children and Youth Studies, 10 (3), 243-256.

Williams, R. B. (1995). Applying recent findings to clinical care in type II diabetes. Pharmacoeconomics, 8 (1), 80-4. 


\section{Perceived Social Support of HIV/AIDS Orphans}

Xu, T., Yan, Z., Duan, S., Wang, C., Rou, K., \& Wu, Z. (2009). Psychosocial Well-being of Children in HIV/AIDS-Affected Families in Southwest China: A Qualitative Study. Journal of Child and Family Study, 18, 21-30. DOI 10.1007/s10826-008-9202-5

Zhao, G., Li, X., Fang, X., Zhao, J., Yang, H., \& Stanton, B. (2007). Care arrangements, grief and psychological problems among children orphaned by AIDS in China. AIDS Care, 19, 10751082. 